\title{
ANALISIS SISTEM PENGENALAN KARAKTER PLAT KENDARAAN DARI CITRA KENDARAAN
}

\author{
I Dewa Gede Angga Prastika ${ }^{1}$, Widyadi Setiawan ${ }^{2}$, Pande Ketut Sudiarta ${ }^{3}$
}

\begin{abstract}
New applications based on advanced technology was created in order to accelerate and facilitate human performance in doing things in different fields. One of them in the field of digital image processing are generally used in the process of pattern recognition. Various applications can be built using pattern recognition techniques in digital image processing one of them in the parking system. Goals and benefits in this final project is to develop license plate recognition system using Histogram as segmentation function, Principal Component Analysis method as extraction function and Euclidean Distancemethods as the classification of characters. The results of the simulation performance of the vehicle license plate character recognition is at $\mathbf{7 7 . 9 0 \%}$ for the percentage of correctly identified all 27 characters and at $22.10 \%$ to the percentage of false identified.
\end{abstract}

Keywords - image processing, euclidean distance, develop license plate recognition system, principal component analysis, histogram

Intisari- Aplikasi-aplikasi baru berbasis teknologi canggih diciptakan guna mempercepat dan mempermudah kinerja manusia dalam melakukan sesuatu dalam berbagai bidang. Salah satunya dalam bidang pengolahan citra digital (image processing) yang umumnya digunakan dalam proses pengenalan pola. Berbagai aplikasi dapat dibangun menggunakan teknik pengenalan pola dalam pengolahan citra digital salah satunya dalam sistem parkir. Tujuan dan manfaat dalam tugas akhir ini adalah untuk mengetahui pembangunan sistem pengenalan karakter plat kendaraan dari suatu citra kendaraan dengan memanfaatkan, metode Histogram sebagai sistem segmentasi karakter dari sistem pengenalan karakter plat kendaraan dari suatu citra kendaraan. Principal Component Analisys sebagai ektrasi ciri dan metode Euclidean Distance untuk klasifikasi karakter. Hasil unjuk kerja pada simulasi pengenalan karakter plat nomor kendaraan dari citra kendaraan berdasarkan hasil simulasi pengenalan karakter plat nomor kendaraan adalah sebesar $\mathbf{7 7 , 9 0 \%}$ untuk presentase dikenali benar dari ke-27 karakter dan sebesar $22,10 \%$ untuk presentase dikenali salah dari ke-27 karakter.

Kata Kunci- image processing, Euclidean Distance, pengenalan karakter plat kendaraan, Principal Component Analysis, histogram

\footnotetext{
${ }^{1}$ Mahasiswa, Jurusan Teknik Elektro dan Komputer Fakultas Teknik Universitas Udayana, Jln. Jalan Kampus Bukit Jimbaran 80361 INDONESIA (telp: 0361-703315; fax: 0361-4321; e-mail: anggaprastika@rocketmail.com

${ }^{2,3}$ Dosen, Jurusan Teknik Elektro dan Komputer Fakultas Teknik Universitas Udayana, Jln. Jalan Kampus Bukit Jimbaran 80361 INDONESIA (telp: 0361-703315; fax: 0361-4321; e-mail: 2widyadi@unud.ac.id, ${ }^{3}$ sudiarta@unud.ac.id
}

\section{Pendahuluan}

Pesatnya perkembangan teknologi saat ini menjadi umpan bagi para ahli untuk menciptakan terobosan-terobosan terbaru berbasis teknologi yang canggih. Terobosan ini diciptakan guna mempercepat dan mempermudah kinerja manusia dalam melakukan sesuatu dalam berbagai bidang. Salah satunya dalam bidang pengolahan citra digital (image processing).

Sistem parkir dibutuhkan pada setiap pusat-pusat keramaian seperti bandara, mall dan tempat-tempat lainnya yang menjadi pusat aktifitas orang banyak. Sistem parkir berfungsi untuk mengatur keluar masuknya kendaraan ke gedung parkir atau lapangan parkir yang terbatas agar kendaraan dapat diparkir sesuai dengan jenis kendaraan pada tempat yang ditentukan oleh sistem.

Analisis Sistem Pendeteksi Posisi Plat Kendaraan Dari Citra Kendaraan (I Dewa Gede Aditya Pemayun , Jurnal Teknik Elektro Universitas Udayana) Dalam jurnal Aditya, memaparkan pendeteksian posisi plat kendaraan bermotor menggunakan teknik pengolahan citra digital dengan menggunakan metode Transformasi Hough dimana sistem akan mendeteksi garis vertikal maupun garis horizontal sebagai kandidat sisi plat, kemudian membandingkan masing masing garis dalam tahap threshoding untuk menemukan pasangan tinggi plat secara vertikal dan lebar plat secara horizontal. [1]

Pemanfaatan pengolahan citra digital yang akan dibahas mengenai pengenalan karakter plat kendaraan bermotor menggunakan teknik pengolahan citra digital dengan menggunakan metode Histogram dan metode principal component analisys sebagai ektrasi ciri dan sebagai sistem segmentasi karakter dari plat tersebut, metode euclidean distance untuk klasifikasi karakter.

\section{TINJAUAN PUSTAKA}

\section{A. Tanda Nomor Kendaraan Bermotor}

Tanda Nomor Kendaraan Bermotor (TNKB) merupakan salah satu bentuk identitas kendaraan yang resmi dikeluarkan oleh Kantor Bersama Samsat. Semua data ini juga tertera dalam Surat Tanda Nomor Kendaraan Bermotor (STNK) yang merupakan surat bukti bahwa nomor polisi itu memang ditetapkan bagi kendaraan tersebut [2]

\section{B. Konsep Dasar Citra}

Citra merupakan suatu gambaran, kemiripan, atau imitasi dari suatu objek. Citra sebagai keluaran suatu sistem perekaman data dapat bersifat optik berupa foto, bersifat analog berupa sinyal-sinyal video seperti gambar pada 
monitor televisi, atau bersifat digital yang dapat langsung disimpanpada suatu media penyimpan. [3]

\section{Citra Digital}

Citra digital merupakan gambar dua dimensi yang dapat ditampilkan pada layar monitor komputer sebagai himpunan berhingga (diskrit) nilai digital yang disebut pixel (picture elements). [4]

\section{Citra Grayscale}

Citra grayscale adalah citra 1 channel yang nilai setiap pikselnya merepresentasikan derajat keabuan, intensitas warna putih atau tingkat intensitas cahaya pada citra tersebut. Nilai pixel pada citra grayscale umumnya memiliki kedalaman pixel 1 byte atau 8 bit yang berada pada rentang nilai 0-255 (256 derajat keabuan) untuk mewakili intensitas cahaya.

\section{E. Low Pass Filter}

Low pass filter adalah metode dasar yang banyak digunakan dalam pengolahan citra digital. Derau dapat ditimbulkan dari proses pengolahan yang tidak sesuai maupun dari gangguan fisis (optik) pada alat yang memberikan konribusi derau pada citra. Derau dapat dikurangi dengan menggunakan low pass filter sehingga citra menjadi lebih halus. [5]

\section{F. Histogram}

Histogram citra adalah salah satu bentuk representasi grafis karakteristik spektral citra yang bersangkutan. Dengan histogram analisis citra dapat memahami citra yang dipelajari misalnya aspek kecerahan dan ketajamannya.

\section{G. Principal Component Analysis ( PCA )}

PCA merupakan transformasi linear untuk menentukan sistem koordinat yang baru dari data. Teknik PCA dapat mengurangi dimensi dari data tanpa menghilangkan informasi penting dari data tersebut.Tujuan dari PCA adalah mencari basis yang baru untuk merepresentasikan ulang data tersebut ke dalam $\mathrm{m}$ variable hasil proyeksi data ke m-dimensi. Dimana $m$ lebih kecil dari $n$. Dengan berkurangnya jumlah dimensi dari data input,maka proses pencocokan data akan berkurang dari $\mathrm{n}$ kali setiap pencocokan menjadi $\mathrm{m}$ kali. Banyaknya dimensi data ditentukan oleh besarnya resolusi image.

\section{H. Euclidean Distance}

Euclidean distance adalah perhitungan jarak dari 2 buah titik dalam Euclidean space. Euclidean space diperkenalkan oleh Euclid, seorang matematikawan dari Yunani sekitar tahun 300 B.C.E. untuk mempelajari hubungan antara sudut dan jarak. Euclidean ini berkaitan dengan Teorema Phytagoras dan biasanya diterapkan pada 1, 2 dan 3 dimensi. Tapi juga sederhana jika diterapkan pada dimensi yang lebih tinggi. [6]

\section{METODE PENELITIAN}

\section{A. Tahapan Penelitian}

Adapun tahapan-tahapan penelitian yang dilakukan adalah sebagai berikut:
1. Pendefinisian masalah untuk sistem yang akan di buat

2. Pengumpulan materi dan data

3. Analisis dan perancangan sistem

4. Implementasi dengan membangun sistem pengenalan karakter plat kendaraan dengan aplikasi MatlabR2012a

5. Pengujian sistem

6. Menarik kesimpulan yang sudah dibuat.

7. Pembuatan laporan

\section{B. Gambaran Umum Sistem Pengenalan Karakter Plat Kendaraan}

Tahap preprocessing merupakan tahap yang wajib dilakukan pada setiap proses pengolahan citra digital. Pada tahap ini, citra digital akan melewati beberapa proses pengolahan untuk selanjutnya citra digital dapat diolah dengan metode histogram.

Dalam penelitian ini menggunakan citra sampel berformat jpeg yaitu citra berwarna sehingga citra sampel yang telah terbaca dan tersimpan di variabel matriks dalam Matlab tersebut adalah citra yang masih mempunyai 3 layer matriks yaitu R-layer, G-layer, dan B-layer. Tiga layer dalam citra sample ini tetap menjadi parameter perhitungan dalam setiap proses pengolahan. Oleh karena itu untuk menghindari melakukan 3 perhitungan yang sama pada setiap layer, citra RGB dengan tiga layer diubah menjadi citra grayscale yang memiliki 1 layer matriks.

Citra sampel yang telah diubah ke dalam bentuk grayscale umumnya memiliki rentang frekuensi rendah sampai frekuensi tinggi. Frekuensi tinggi pada citra ini menimbulkan noise atau interference sehingga diperlukan penapisan guna meredam noise. Pada proses pendeteksian plat kendaraan pada sebuah citra kendaraan, noise sangat mengganggu proses pendeteksian. Noise dapat mengaburkan kandidat sisi plat dalam citra dengan objek-objek lainnya disekitar plat. Oleh karena itu, diperlukan penerapan low pass filter guna meredam noise yang disebabkan oleh frekuensi tinggi. Lazimnya derau memiliki spektrum frekuensi ruang (spatial frequency) yang jauh lebih tinggi dari komponen-komponen citra, karena derau ini tidak mempunyai ikatan dengan komponen-komponen citra. Low pass filter mampu mengurangi noise dengan cara menghaluskan sebuah citra.

Histogram citra dipresentasikan dengan dua bentuk: pertama tabel yang memuat kolom-kolom nilai piksel jumlah absolut setiap nilai piksel, jumlah komulatif piksel, presentase absolut setiap nilai, dan presentase komulatifnya; kedua, gambaran grafis yang menunjukkan nilai piksel pada sumbu $\mathrm{x}$ dan frekuensi kemunculan pada sumbu y. Melalui gambaran grafis histogram ini, secara umum dapat diketahui sifat-sifat citra yang diwakilinya.

Setelah itu PCA mencari basis yang baru untuk merepresentasikan ulang data tersebut ke dalam $m$ variabel hasil proyeksi data ke m-dimensi. Dengan berkurangnya jumlah dimensi dari data input, maka proses pencocokan data akan berkurang dari $\mathrm{n}$ kali setiap pencocokan menjadi $\mathrm{m}$ kali. Banyaknya dimensi data ditentukan oleh besarnya resolusi image. Hal ini menyebabkan dimensi data menjadi sangat 
besar. Semakin besarnya dimensi data menyebabkan waktu pencocokan per data semakin besar juga.

Euclidean distance digunakan untuk menghitung jarak antar karakter. Dimana data hasil dari ekstrasi ciri sudah di masukan kedalam kelompok - kelompok tertentu sehingga sudah di kenali dari karakter plat kendaraan tersebut. Jumlah sampel yang digunakan adalah 20 sample yang berbeda sehingga dimana dari ke 20 sampel yang di pakai kita ketahui presentase berapa jumlah plat kendaraan yang berhasil dikenali karakternya. Untuk alur flowchart-nya dapat dilihat pada gambar 1

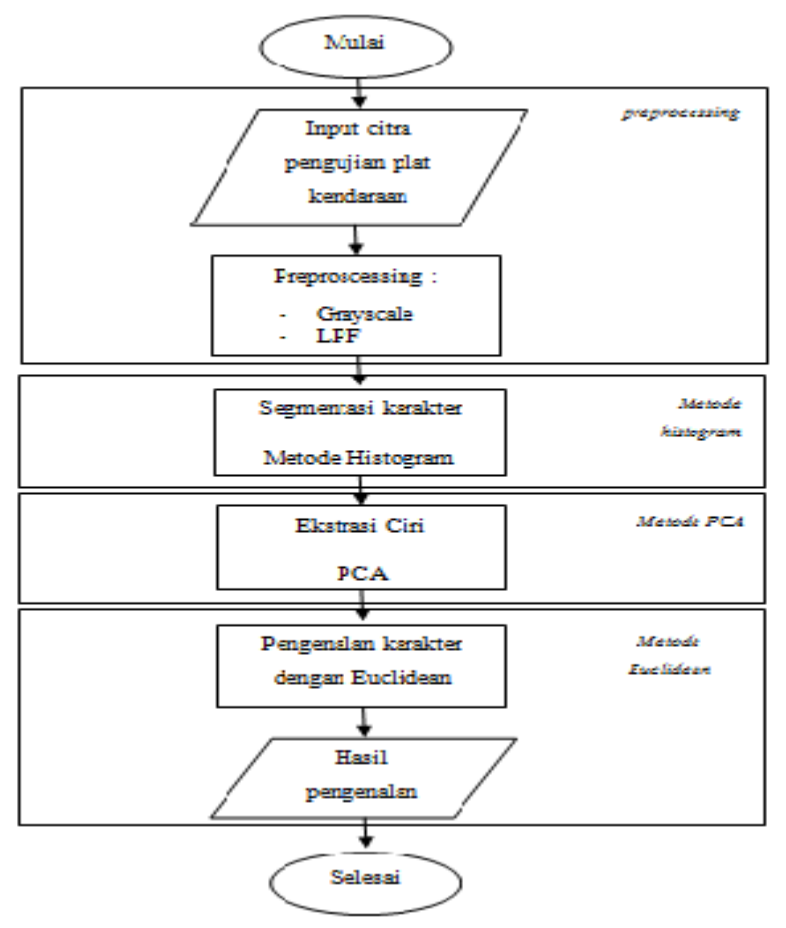

Gambar 1: Alur Flowchart Pengujian Program

\section{HASIL DAN PEMBAHASAN}

Pada penelitian ini dibahas mengenai analisis sistem pengenalan karakter plat kendaraan dari citra kendaraan yang menggunakan 20 sampel citra uji yang berbeda. Citra uji yang yang akan diujikan ke dalam sistem ini diambil dengan kamera VGA dengan resolusi yang relatif kecil untuk perkembangan kamera digital saat ini yaitu sebesar 640 x 480 . Pemilihan resolusi yang relatif kecil ini atas dasar beberapa faktor yang mempengaruhi secara langsung proses simulasi. Adapun faktor-faktor tersebut antara lain, dapat mempengaruhi kecepatan proses sistem. Semakin besar resolusi citra yang diujikan maka semakin banyak piksel yang harus diolah oleh program sehingga membutuhkan waktu yang lebih lama. Dengan resolusi 640 x 480, sebuah citra berwarna dapat merepresentasikan cukup warna yang dibutuhkan dalam proses segmentasi karakter dalam penelitian, namun tetap memperhatikan jarak akuisisi citra. Dalam penelitian ini, citra sampel diambil pada jarak $150 \mathrm{~cm}$ dengan ketinggian $50 \mathrm{~cm}$ diatas lantai.

\section{A. Sampel Citra}

Data sampel citra yang didapatkan dilapangan berupa citra berformat jpg beresolusi 640 x 480 yang merepresentasikan objek kendaraan dengan plat standar. Data tersebut akan diolah menggunakan sistem simulasi dengan bantuan program Matlab. Pada tahap awal sistem ini akan melakukan pembacaan citra ke dalam program Matlab.Seperti yang digambarkan pada Gambar 2.

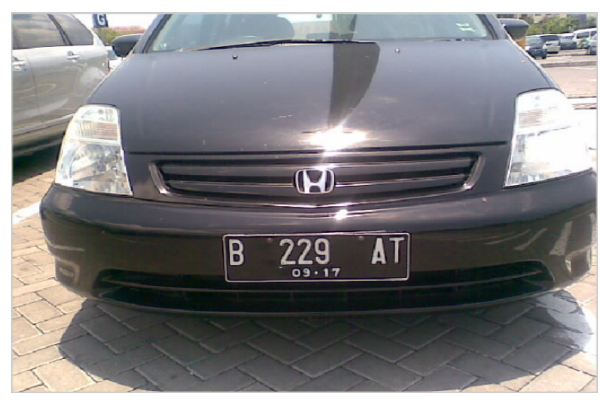

Gambar 2: Sampel Citra B229AT.jpg

Citra ini selanjutnya dibaca program Matlab sebagai 3 matriks dua dimensi. Dalam proses pembacaan oleh Matlab, 3 matriks yang dihasilkan tiap matriks akan mewakili masingmasing layer dalam citra sampel yaitu citra RGB.

\section{B. Pengujian Citra RGB ke Grayscale}

Sampel citra pertama yang masih dalam format RGB selanjutnya masuk ke tahap kedua yaitu konversi citra awal dari citra RGB menjadi citra grayscale. Seperti yang di tunjukan pada gambar 3 .

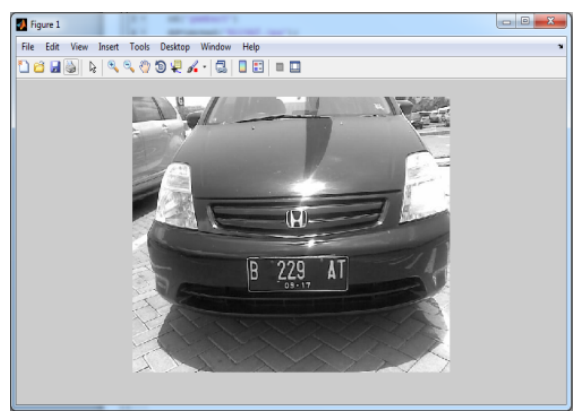

Gambar 3: Hasil Konversi Sampel Citra RGB B229AT.jpg ke Grayscale

Pada tahap konversi citra dari RGB ke grayscale ini tidak ada perbedaan antara skenario vertikal, horizontal, maupun gabungan keduanya. Hal ini disebabkan konversi citra dari citra RGB ke grayscale hanya menyederhanakan warna citra, sehingga mempercepat proses pendeteksian garis pada tahap selanjutnya.

\section{Pengujian Hasil Filtering}

Dari tahap grayscale, citra akan melewati tahap filtering menggunakan filter pererataan. Proses filtering penting dilakukan dalam pengolahan citra digital bertujuan untuk 
mengurangi noise yang terkandung dalam citra yang dapat menjadi salah satu faktor penghambat proses pendeteksian tepian plat kendaraan.

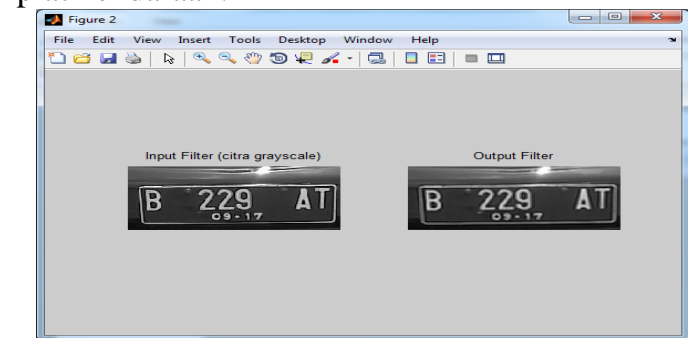

Gambar 4: Perbandingan Citra Sebelum dan Sesudah Filtering

Citra hasil dari proses filtering akan tampak lebih blur (buram) dari citra input sebelum melewati filter. Seperti pada Gambar 4 menunjukkan bahwa jumlah noise direduksi oleh filter pererataan sehingga tepian plat kendaraan tampak lebih halus tanpa noise.

\section{Pengujian Hasil Hitam Putih dan Pemotongan tepi dari \\ Plat}

Tujuan dari proses ini untuk mempermudah pengenalan karakter plat kendaraan. Dimana hasil dari proses ini selanjutnya dilakukan pemotongan tepi agar menghilangkan garis putih yang terdapat di plat kendaran karena dapat mengganggu hasil dari pendeteksian karakter plat kendaraan.

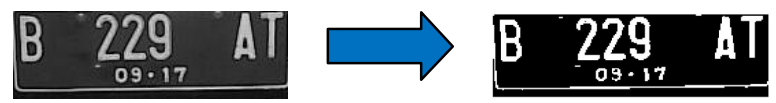

Gambar 5: Hasil konversi Sampel Citra Grayscale ke Hitam Putih

Dapat dilihat pada Gambar 5 dimana terdapat perubahan dari citra awal yang semula berwarna keabu - abuan berubah menjadi hitam putih sehingga perbedaan warna karakter pada plat tersebut terlihat jelas perbedaannya dengan warna dasar pada plat tersebut.
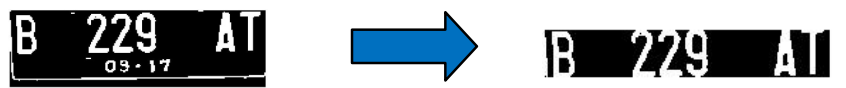

Gambar 6: Hasil Pemotongan Sampel Citra Hitam Putih

Dan pada Gambar 6 dimana hasil dari sampel citra yang sudah diubah menjadi citra hitam dan putih kemudian di potong tepinya yang bertujuan untuk mempermudah pendeteksian karakter plat kendaraan sehingga tidak mengganggu hasil pendeteksian karakter plat.

\section{E. Pengujian Segmentasi dengan Histogram}

Dari hasil proses pemotongan tepi kemudian disegmentasi dengan metode histogram dimana pada metode ini citra akanmelalui gambaran grafis histogram, secara umum dapat diketahui sifat-sifat citra yang diwakili dari setiap citra. Dimana di setiap citra yang memiliki nilai 0 maka disana yang dijadikan sebagai titik potong, dan juga di awal dan akhir dari citra di beri nilai 0 yang bertujuan sebagai batas awal dan batas akhir dari segmentasi.
Dapat dilihat pada Gambar 7 dimana setiap karakter memiliki nilainya sendiri, pada saat nilai awal dan akhir setiap karakter tersebut 0 maka itu yang di jadikan patokan pemisah antar karakter tersebut.hasil dari proses histogram selanjutnya akan dijadikan input pada metode selanjutnya.

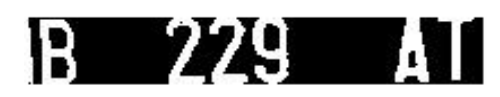

(a)

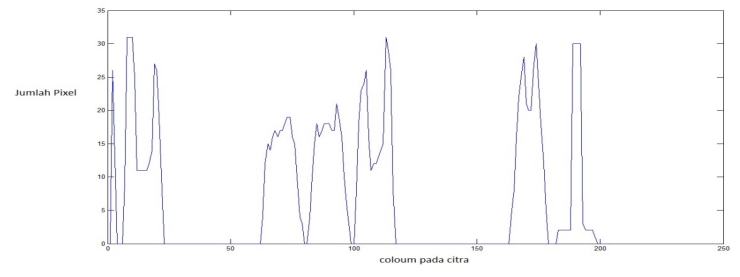

(b)

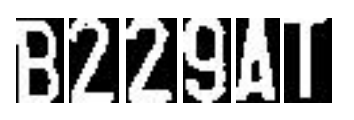

(c)

Gambar 7: Citra Awal (a), Hasil Citra yang di Histogram (b), Citra Hasil Segmentasi (c)

F. Pengujian Metode PCA ( Principal Component Analysis)

Setelah hasil dari histogram didapatkan maka langkah selanjutnya adalah mensegmentasi dari citra plat kendaran tersebut dimana citra plat kendaraan tersebut dipecah per karakter dari kendaran. Di dalam PCA dimana karakter yang dipakai adalah 27 karakter dikarenakan kurangnya sampel karakter citra yang di peroleh, 27 karakter tersebut terdiri dari 10 angka $(0,1,2,3,4,5,6,7,8,9)$ dan 17 Karakter $(\mathrm{A}, \mathrm{B}, \mathrm{C}$, D, E, F, H, J, K, L, M, N, O, S, T, V, W). Dalam proses ini citra dari masing - masing karakter disamakan dimensinya yaitu 32 x 16 tujuan dari menyamakan dimensi dari setiap karakter yaitu untuk memudahkan pengenalan dari setiap karakter pada metode selanjutnya. Inputan dari PCA berupa citra yang matriknya 32 x 16 selanjutnya dimana citra yang matriknya 32 x 16 diubah menjadi vektor coloum [512 x 81] yang disimbolkan dalam matlab sebagai VZM setelah diubah menjadi vektor kolom lalu dikalikan dengan perkalian matrik dengan matrik proyeksi yaitu [512x10] yang di simbulkan dalam Matlab sebagai nilai $\mathrm{V}$.

Dimana untuk mendapatkan nilai PCA digunakan rumus VZM x V sehingga mendapatkan hasil [81x10] yang disimbolkan dalam matlab sebagai CV. Jadi untuk mendapatkan nilai PCA dari satu karakter plat kendaraan maka matrik awal citra diubah dahulu menjadi menjadi matrik kolom lalu di kalikan dengan matrik proyeksi sehingga nilai untuk satu citra karakter suatu plat adalah [1x10].

\section{G. Pengujian Euclidean Distance}

Setelah pengujian melalui metode PCA ( Principal Component Analisys ) selanjutnya yaitu pengujian metode Euclidean Distance dimana dalam tahapan ini hasil dari PCA akan dibandingkan dengan menggunakan euclidean distance 
untuk mencari jarak terdekat. Kemiripan di dapat dari perhitungan jarak dari nilai terdekatnya

\section{H. Hasil Simulasi Pendeteksian Horizontal pada 20 Citra} Sampel

Simulasi sistem pengenalan karakter plat nomor kendaraan ini selanjutnya akan mengolah 20 citra sampel dengan karakteristik yang berbeda baik dari segi jenis, karakter, dan warna kendaraan. Hasil dari proses simulasi sistem pengenalan karakter plat nomor kendaraan didapatkan hasil ada beberapa karakter yang tidak dapat melanjutkan proses pengenalan dikarenakan ada beberapa karakter yang gagal pada proses segmentasi. kegagalan pada saat proses segmentasi dikarenakan terlalu gelapnya sample citra yang didapatkan sehingga pada saat segmentasi program tidak dapat menetapkan titik potong perkarakter tersebut. Dan juga ada beberapa karakter yang dikenali tetapi tidak sesuai dengan karakter awal dikarenakan kurang variasinya sample citra perkarakter yang dimiliki dan juga dikarenakan adanya ketidak sempurnaan pemotongan perkarakter pada saat segmentasi karakter yang dikenali benar adalah 79 karakter dan yang dikenali salah adalah 33 karakter dari jumlah keseluruhan 112 karakter, Jadi presentase keseluruhan dikenali benar sebesar $70,54 \%$ dan presentase dikenali salah sebesar $29,46 \%$.

\section{SimpUlaN}

Berdasarkan hasil simulasi sistem pengenalan karakter plat nomor kendaraan yang telah dilakukan pada bab sebelumnya maka diperoleh beberapa simpulan sebagai berikut:

1. Pada penelitian Tugas Akhir ini telah berhasil membangun sistem pengenalan karakter plat nomor kendaraan dari citra kendaraan dengan menggunakan metode histogram, metode Principal Component Analisys, dan metode Euclidean Distance pada program aplikasi Matlab.

2. Hasil unjuk kerja pada simulasi sistem pengenalan karakter plat nomor kendaraan berdasarkan metode histogram, Principal Component Analisys, dan metode Euclidean Distance. Dan untuk hasil simulasi pengenalan karakter plat nomor kendaraan adalah sebesar $70.54 \%$ untuk presentase dikenali benar dan sebesar $29.46 \%$ untuk presentase dikenali salah. Beberapa karakter yang salah dikarenakan ada beberapa karakter yang gagal pada proses segmentasi seperti yang terjadi pada citra ke-4, citra ke-5, ke-6, ke-11, dan citra ke-19. Dan juga ada beberapa karakter yang dikenali tetapi tidak sesuai dengan karakter awal dikarenakan kurang bervariasinya sample citra perkarakter yang dimiliki dan juga dikarenakan adanya ketidak sempurnaan pemotongan perkarakter pada saat segmentasi seperti pada karakter D, dan juga ada beberapa karakter yang mirip seperti karakter 9 dan karakter 0 .

3. Dari unjuk kerja pada simulasi sistem pengenalan karakter plat nomor kendaraan berdasarkan metode histogram, Principal Component Analisys, dan metode Euclidean Distance. Jumlah karakter yang di segmentasi dengan benar sebanyak 80 karakter.

\section{REFERENSI}

[1]. Pemayun. “Analisis Sistem Pendeteksi Posisi Plat Kendaraan Dari Citra Kendaraan,” Tugas Akhir, Universitas Udayana, Bali, Indonesia, 2015.

[2]. Anomim. Nomor Polisi. http://id.wikipedia.org/wiki/Nomor_polisi. Diakses tanggal : 20 Juni 2014.

[3]. G. W. Awcock, Applied Image Processing.Singapore. McGraw-Hill. 1996.

[4]. T. Sutoyo, E. Mulyanto, V. Suhartono, O. D. Nurhayati, Wijanarto Teori Pengolahan Citra Digital. Indonesia, Yogyakarta: ANDI. 2009.

[5]. Pitas, Loannis. Digital Image Processing Algorithms. Prentice Hall International (Uk) Ltd. 1993.

[6]. Anugraha. (2015) Teori Pengukuran Jarak. [Online]. Available: http:www.blogs.itb.ac.id/anugraha/2014/09/10/teori-pengukuran-jarak/ 
[Halaman ini sengaja dikosongkan] 